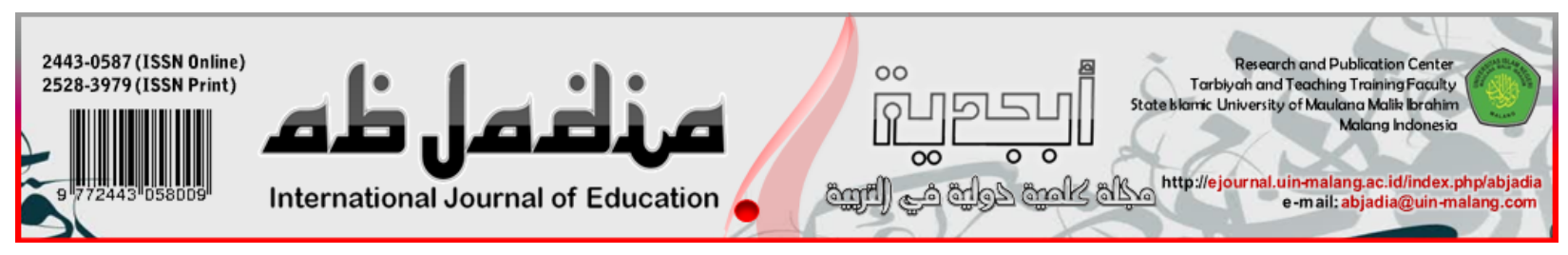

\title{
MAPPING STUDENTS' INTEREST IN SELECTING RELIGIOUS PROGRAMS IN MADRASAH ALIYAH DARUL ILMI BANJARBARU
}

\author{
*Muhammad Efendi ${ }^{1}$, Siswandi Andika Putra ${ }^{2}$, Muniratul Mukaramah ${ }^{3}$ \\ ${ }^{1}$ Geography Study Program, FISIP Lambung Mangkurat University, Banjarmasin, Indonesia \\ ${ }^{2}$ Department of Islamic Education, UIN Antasari, Banjarmasin, Indonesia \\ ${ }^{3}$ Madrasah Aliyah Darul Ilmi, Banjarbaru City, South Kalimantan, Indonesia
}

\begin{abstract}
Article History:
Received: 2021-09-27

Revised: 2021-11-24

Accepted : 2021-12-14

Published : 2021-12-26
\end{abstract}

\section{Keywords:}

Interest; Student; Religious Program

* Correspondence Address:

muhammad.efendi@ulm.ac.id

\begin{abstract}
Interest is a moment of an intensively directed tendency to an object that is considered important because there is always a strong effective element (feeling and emotional). Interest also displays the attitude that appears in a person. In addition, interest is an impulse that causes the attachment of individual attention to certain objects such as work, lessons, objects, and people. The object of this research is the interest of class X students (Religious Program) at Madrasah Aliyah Darul Ilmi Banjarbaru. While the subjects in this study were all students of class X (Religious Program) at Madrasah Aliyah Darul Ilmi Banjarbaru as many as 50 students. Based on the results of data analysis, It can be concluded that the selection of religious programs at Madrasah Aliyah Darul Ilmi class X for the 2020/2021 academic year can support the talents of students. The factors that influence students' interest in the religious specialization can be seen from the talent factor is said to be high with an average of $86 \%$, the achievement factor is said to be high with an average of $80 \%$, the ideals factor is said to be high with an average of $72 \%$, the achievement factor is said to be high with an average of $72 \%$. motivation is said to be high with an average of $74 \%$, interest factors are said to be quite high with an average of $61 \%$, school environment factors are said to be quite high with an average of $69 \%$, family environmental factors are said to be quite high with an average of $55 \%$, and friends are said to be quite high with an average of $51 \%$.
\end{abstract}

\section{C) Introduction}

Quality education must include two main dimensions, namely academic orientation and basic life skills orientation. According to Zulaeha (2013) education that produces academically-oriented achievement means being able and has a measure of success, while life skills-oriented education is education that allows students to survive in real life. To create quality resources that are successful and have use-value, an educational service approach is needed that refers to the talents, interests, abilities, and intelligence of students (Efendi, 2014).

This is following the purpose of education in writing Hakim (1985) stated education is an effort to provide opportunities for students to develop talents optimally, according to their needs and abilities, so that they can manifest themselves to function fully by personal needs and the needs of the wider community. The role of institutions or schools in achieving this requires acceleration and correlation of the latest curriculum to develop various kinds of specializations to increase students achievement. 
High learning achievement is part of the learning effort because the success in learning can be influenced by external and internal factors (Astuti et al., 2020). Madrasah Aliyah (MA) level is a forum where students determine the specialization they will choose, with the implementation determined by various parties. According to Rahmadani (2016), some things need to be determined by the school regarding the ability of students in determining specialization, besides that the parents also influence the interests and desires of students. The school in its implementation determines the specialization based on the value obtained by students for the subjects given (Reza et al., 2017). Students can of course determine the desired specialization based on their abilities.

The dominant factors in influencing students to choose a religious specialization at Madrasah Aliyah Darul Ilmi in class X (ten), namely: (1) talent; (2) interest; (3) ideals; (4) motivation, and (5) achievement. However, regardless of popular problems or not, interests as understood and used by people so far can affect the quality of student achievement in certain fields of study (Sudarmono et al., 2018). Each program has various enthusiasts, they (students) have certain considerations before choosing an interest, as well as students who choose religious and social science programs at Madrasah Aliyah Darul Ilmi.

The distribution of student data at Madrasah Aliyah Darul Ilmi based on specialization is gradual which is quite different between religious interest and social science. Student interest in religious programs is relatively lower than social science programs, this is based on field facts that the learning system at Madrasah Aliyah Darul Ilmi uses a conventional curriculum, this system combines salafiyah religious learning with general learning. The general learning system is carried out in the afternoon and salafiyah religious learning in the morning. This situation gives rise to the perception of multiple learning and repeated mastery of material, especially religious programs at Madrasah Aliyah Darul Ilmi, for example: (1) fiqh, (2) ushul fiqh, (3) ilmu kalam, and other sciences (Efendi et al., 2020) that are in line with learning in the mu'allimin program at the Darul Ilmi Islamic Boarding School Foundation, this is the reason for the low interest of students to study and attend religious program classes.

Etymologically, interest is the attention, liking or inclination of the heart towards something desired. Interest is the tendency of a person who is involved in a particular field and feels interested in it, interest also contains an element of a high desire to continue to learn and want to know the object to be sought as a manifestation of the actualization of insight and knowledge. The rule of interest in its implementation must be supported by concrete actions as a necessity in knowing and learning from the object (Dalimunthe, 2020).

Interest is a moment of a tendency that directed intensively at an object that is considered important because there are elements of strong feelings and emotions. Interest also displays the attitude of a person that appears in a person. In addition, interest is an impulse that causes the attachment of individual attention to certain objects such as work, 
lessons, objects, and people. Interest is related to cognitive, affective, and motor aspects, as well as part of the source of motivation to do what you want (Sujianto, 2020).

Based on some of the definitions above, it can be concluded that interest is the willingness and attention of the soul which is active to accept something from the outside and consequently causes a tendency of the heart to something that interests him. Meanwhile, if it is related to students' interest in choosing a religious program, interest means the tendency of a person's heart in choosing a religious program organized by the school.

The selection of specializations is carried out by students when registering in SMA/MA based on report cards for junior high schools/madrasah tsanawiyah (SMP/MTs) or the equivalent, national exam scores for SMP/MTs or equivalent, with the recommendation of a guidance and counseling teacher at SMP/MTs of the same level, as well as the results of the placement test or aptitude and interest tests by psychology (Herianto, 2020).

Students can choose a minimum of three from the four subjects contained in one specialization, one subject whose learning load is not taken is transferred to cross-interest subjects. In the implementation of the specialization program, students are required to follow certain subjects that are concentrated in cross-interest subjects. Students who take religious specialization, the concentration of cross-interest subjects must be outside the chosen specialization subject, which also applies to students who choose social studies and language specialization programs (Putra, 2021).

\section{[Q] Method}

This type of research is field research, a research that is carried out systematically by raising data in the field that is following the factual reality. The approach used in this study is qualitative (Arikunto, 2006). This research is designed with data collection in a natural setting to interpret the phenomena that occur (Sugiyono, 2008). This study was used to describe everything related to student interest in choosing religious programs at Madrasah aliyah Darul Ilmi class X for the 2020/2021 academic year. The subjects of this study were students at the Madrasah aliyah Darul Ilmi with a total of 684 students, while the object of this study were all students in class $X$ (ten) of the religious program of the Madrasah aliyah Darul Ilmi with a total of 50 students.

The research data that has been collected are fully analyzed interactively. Data analysis is carried out every time data collection in the field is carried out on an ongoing basis. data in the form of sentences collected through observation, questionnaires, documentation, and others have been arranged in an orderly manner. Then, according to Miles and Huberman (1992), in the process of data analysis, there are three main components that every qualitative researcher really must understand, namely (1) data reduction, (2) data presentation, (3) drawing conclusions or verification. From the 
formulation of the data above, it can be seen that data analysis intends to collect data, namely the activity of organizing data by organizing, sorting, grouping, coding, and categorizing it (Moleong, 2007).

Conclusions are drawn through a continuous verification process throughout the research. Drawing conclusions in this research, after the data is collected, which ones are needed and which ones are not needed, then a network is arranged related to the research problem, namely how students are interested in choosing religious programs in Madrasah Aliyah class X for the academic year 2020/2021 at Madrasah Aliyah Darul Ilmi which was then verified.

\section{ipiscussion}

A person's interest in a certain object or thing will not appear by itself, each individual has diverse interests and will arise automatically through the process. Interest will continue to grow with the interaction of individuals with the environment. Many factors affect a person's interest, one of them is a psychological factor which can be identified by observing the personality dimensions. Next Rahmadani (2016) explaining the Trait-Factor theory, he said that a person's personality can be described by identifying existing traits and the results of psychological tests that refer to personality dimensions. Sukardi and Sumiati (1993) explained, the internal factors that influence interest can be distinguished from one to another, these cannot be separated from each other, because each individual is unique. The indicators that influence students in choosing specializations include (1) interest; (2) ideals; (3) talent; (4) learning achievement results, and (5) motivation.

\section{Talent}

The development of madrasah aliyah student education within the school environment is not entirely the responsibility of the education provider, in this case, the Madrasah aliyah Darul Ilmi Banjarbaru institution requires cooperation with parents in providing education and coaching, especially to shape the child's personality which will be the provision of the next life (Arisanty \& Efendi, 2017). Next Kurniati (2004) stated that talent (aptitude) is defined as an innate ability, as a potential that still needs to be developed and trained to be realized. In this case, talent requires training and education so that an action can be carried out in the future (Nurhasanah et al., 2012), an ability that is inherent and possessed by everyone that can be used to learn things quickly and even some of them can learn in a short time and get very good results, in other words, talent has been inherent in humans since they were born.

Each person's talent is greatly varies and different from others. Based on picture 1 below, it can be described from 50 respondents that $88 \%$ of students stated it was true that choosing a religious program could support individual talents, $86 \%$ of students said they were confident in their choice, and $84 \%$ of students believe that they can determine 
their talents. Observing the composition of respondents' answers in picture 1, it can be mapped that the factors that influence students' interest in choosing religious programs at Madrasah aliyah Darul Ilmi are being able to support their talents.

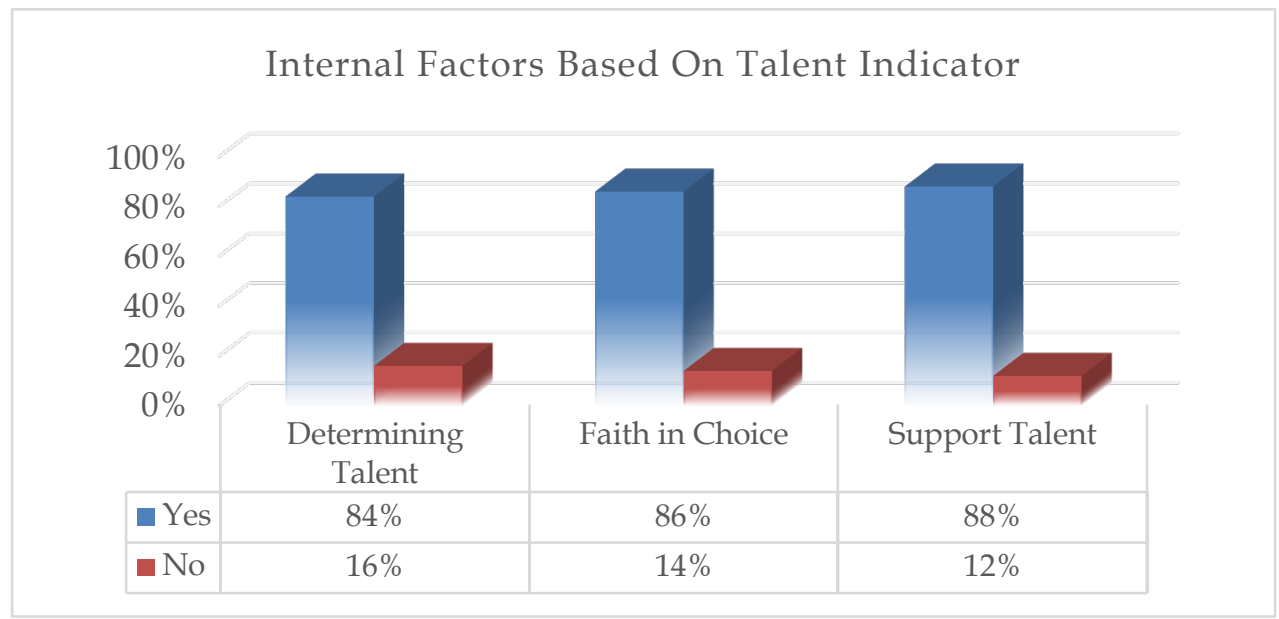

Picture 1. Internal Factors Based on Talent Indicator

\section{Achievement}

Student learning is always a process, it is possible that there are students who experience problems in learning achievement (Syafi'i et al., 2018). Some students often excel and some fail in their achievement, failure in learning is not only caused by students who are not interested or teachers who fail to teach but there are other factors that influence it, both internal and external factors. This matter needs to be harmonized with the activeness of an educator in tracking students' interests and achievements by multiplying their psychological and physical so that learning failures can be given a solution and together to improve them in the future to achieve maximum learning achievement (Putra, 2021). In addition, as stated by Oemar Hamalik (2011) in his book The Teaching and Learning Process states that learning is modifying or reinforcing behavior through experience. According to this understanding, learning is a process of an activity and not a result or goal.

Based on Picture 2 above, it can be explained that from 50 respondents there were $86 \%$ of students stated it was true that choosing a religious program could increase achievement, $80 \%$ of students stated that it could be useful for the future, and $74 \%$ of students stated that it was true that it was able to support their innate talent. Observing the composition of respondents' answers in Picture 2, it can be mapped that the factors that influence students' interest in choosing religious programs at Madrasah aliyah Darul Ilmi are being able to increase academic achievement. 


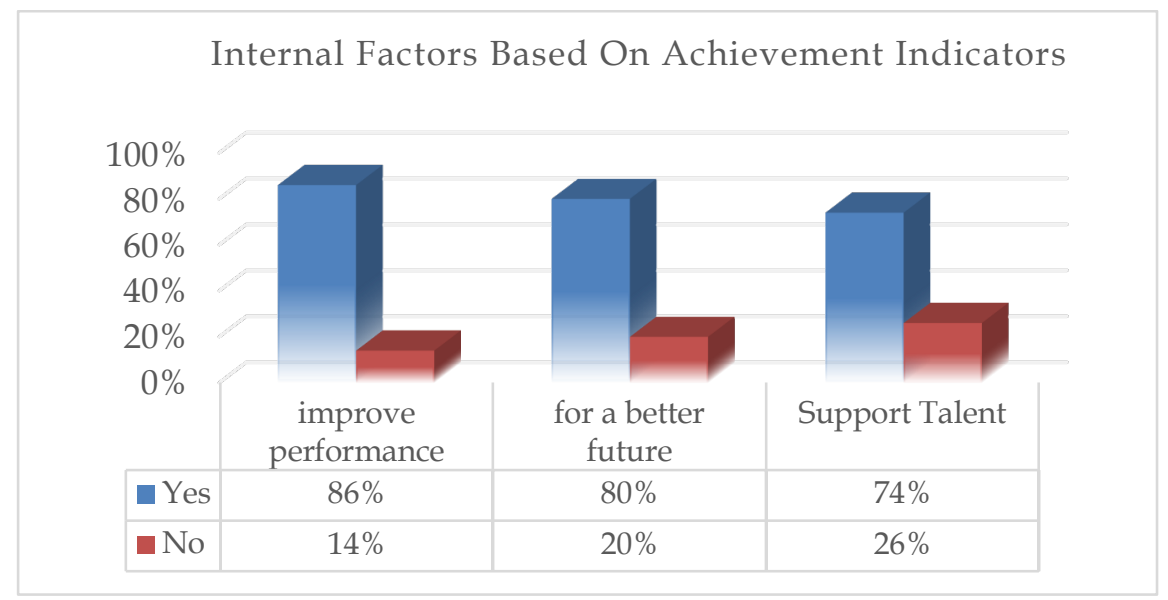

Picture 2. Internal Factors Based on Achievement Indicators

\section{Ambition}

An individual certainly has a direction and purpose in life, a planned life guide is described in a language that we often hear with unfulfilled ideals or desires, as an educator, of course, has noble ideals in making himself a figure who can be role models for his students. This is not an easy matter if we as educators only intend it, but it must be realized with intention, effort and, hard work. In realizing the ideals, innovation and strong determination are needed by referring to the basic foundation of an individual who continues to grow as well as strong determination and environmental support that always accompanies him. Likewise, the ideals that exist in students who become reference material and motivate themselves.

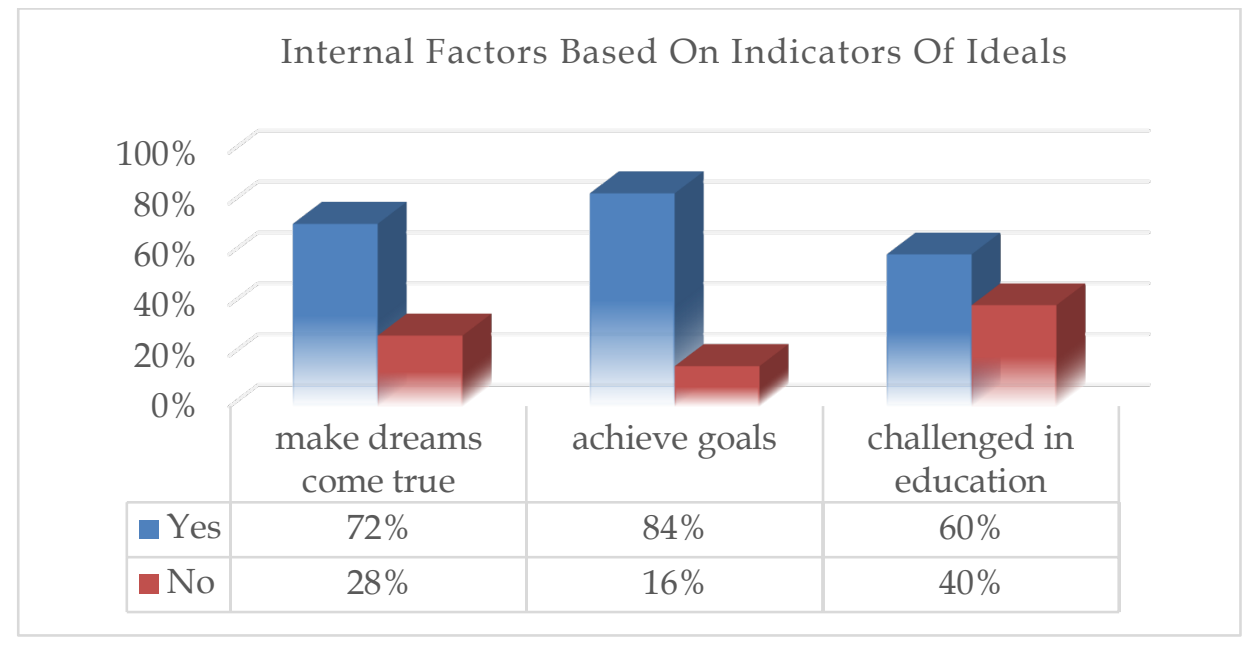

Picture 3. Internal Factors Based on Indicators of Ideals

Based on Picture 3 above, it can be explained that from 50 respondents, $84 \%$ of students stated that they were right by choosing a religious program to achieve their goals, $72 \%$ stated that choosing a religious program would realize their goals, and $60 \%$ of students stated that they were challenged with religious programs because of the substance. the subjects taught are different and unique from other specialization programs. Observing the composition of respondents' answers in Picture 3, it can be 
mapped that the factors that influence students' interest in choosing religious programs at Madrasah Aliyah Darul Ilmi are being able to achieve their goals.

\section{Motivation}

Motivation is a process to activate motives into actions or behavior to meet needs and achieve goals, or the state and readiness in individuals that encourage their behavior to do something in achieving certain goals (Uzer Usman, 2009). Based on Picture 4, it can be explained that from 50 respondents there are $78 \%$ of students stated that they were motivated in choosing a religious specialization program, then $76 \%$ of students said they were able to compete with other friends and $68 \%$ of students stated that they were motivated from the information submitted about the religious specialization program provided by Madrasah Aliyah Darul Ilmi. Observing the composition of respondents' answers in Picture 4, it can be mapped that the factors that influence students' interest in choosing religious programs at Madrasah Aliyah Darul Ilmi are being motivated by religious programs because they think that religious programs in the future are able to bridge further education to pursue higher education.

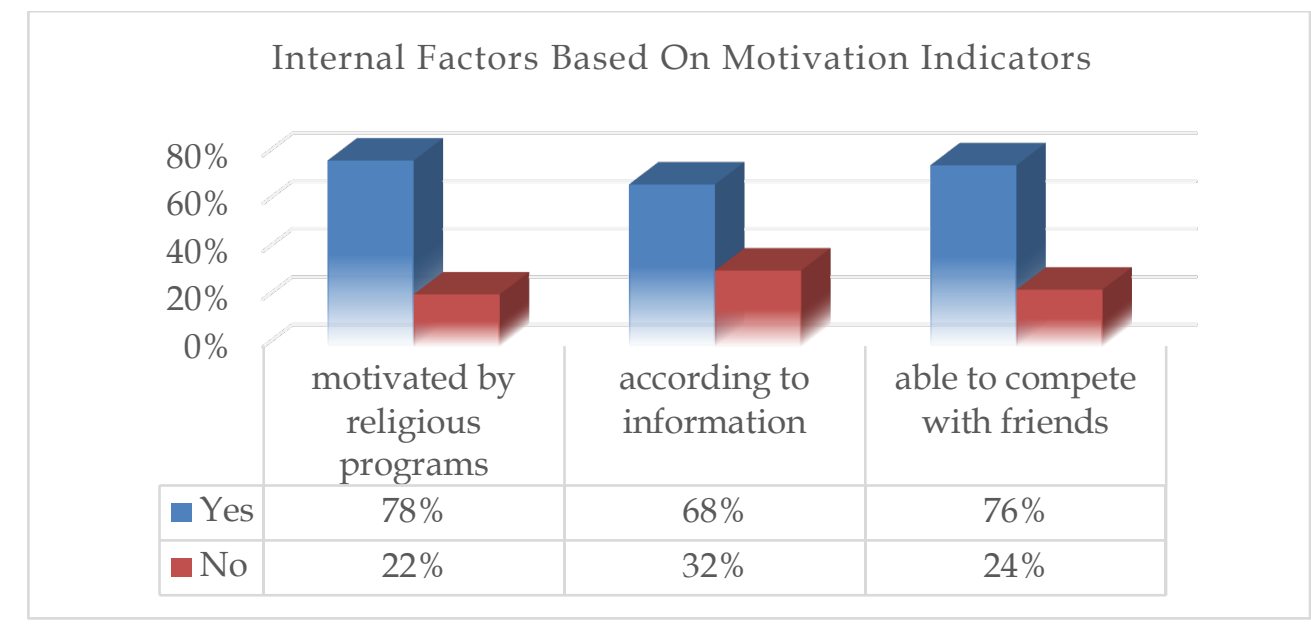

Picture 4. Internal Factors Based on Motivation Indicators

\section{Interest}

Interest is the self-actualization of activities that exist in individual students and as a result of the activities, students tend to have a heart desire to learn in science, skills, teaching, and or educational experience as well as knowledge. The physical form that always remembers and pays attention to some activities or activities is a small part of interest. If the individual has an interest, it will correlate with his activities and cause a happy heart feeling and will occur continuously in his life (Slameto, 2003). Furthermore, according to Krianasari \& Salsabila (2020) the embodiment of the interests possessed by students can help them understand the lesson in a faster period, compared to students who do not have an interest.

Based on Picture 5 above, it can be explained that from 50 respondents there were $72 \%$ of students stated it was true that the specialization offered by the school was correct. 
Furthermore, 50\% of students stated that they were interested in religious specialization because at first glance it looked cool from other specializations and $60 \%$ of students stated that they consulted both teachers and parents before choosing a specialization. Observing the composition of respondents' answers in Picture 5, it can be mapped that the factors that influence students' interest in choosing religious programs at Madrasah Aliyah Darul Ilmi are the specializations offered by the school because according to students it is appropriate and following the development of foundations with Islamic principles and able to provide learning correlation. both in general and in specific studies on religious programs.

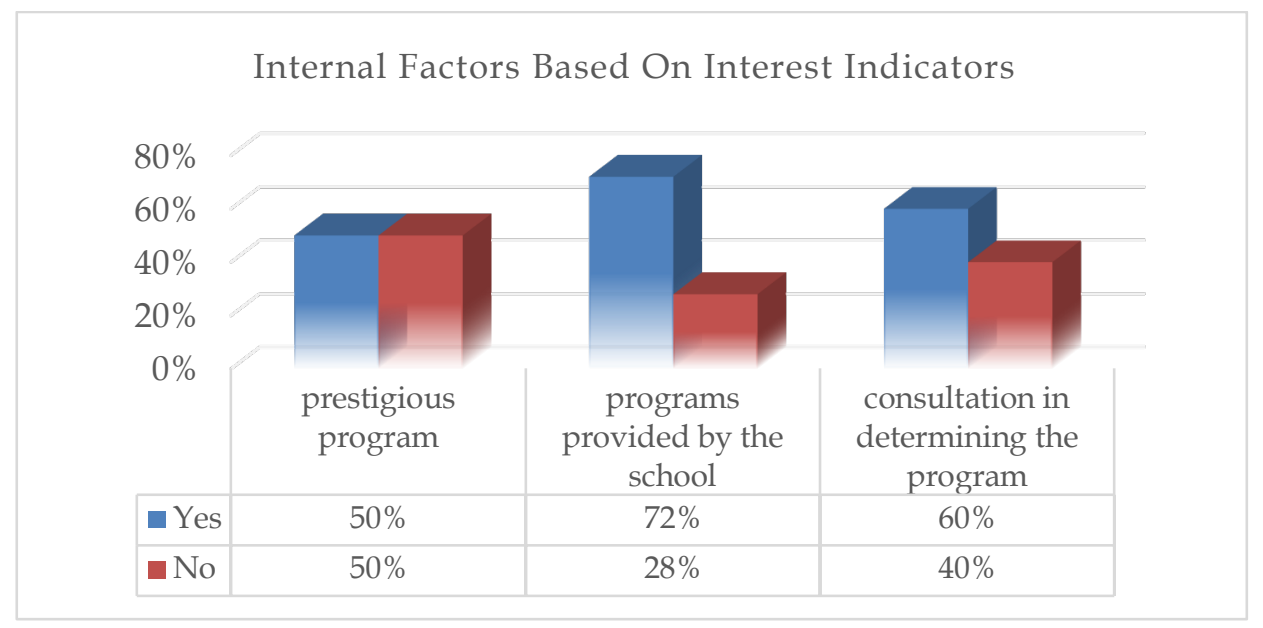

Picture 5. Internal Factors Based on Interest Indicators

\section{闻 Conclusion}

Based on the results of research in the field, it can be mapped that the indicators of the distribution of student interest in choosing religious programs at Madrasah aliyah Darul Ilmi class $X$ for the academic year 2020/2021 are influenced by; (1) interest; (2) ideals; (3) talent; (4) learning achievement results and (5) motivation, then described in full as follows:

There are $88 \%$ of students stated that choosing a religious program can support individual talents, $86 \%$ of students stated that they are confident in their choice and $84 \%$ of students believe that they can determine their talents. The most dominant factor is being able to support the talent it has. There were $86 \%$ of students stated it was true that choosing a religious program could improve academic achievement, $80 \%$ of students stated that it could be useful for the future, and $74 \%$ of students stated that it was true that it was able to support their innate talent. The most dominant factor is being able to improve academic achievement. There are $84 \%$ of students who stated that choosing a religious program could achieve their goals, $72 \%$ stated that choosing a religious program would realize their goals, and $60 \%$ of students stated that they were challenged by religious programs because the substance of the subjects taught was different and unique from the program. other interests. The most dominant factor is being able to achieve goals. There were $78 \%$ of students who stated that they were motivated in choosing a 
religious specialization program, then $76 \%$ of students said they were able to compete with their friends and $68 \%$ of students stated that they were motivated from the information submitted about the religious specialization program provided by the madrasa aliyah. The most dominant factor is being motivated by the delivery of the madrasah about the Religious program. There are $72 \%$ of students who stated that the specialization offered by the school was correct. Furthermore, $50 \%$ of students stated that they were interested in religious specialization because at first glance it looked cool from other specializations and $60 \%$ of students stated that they consulted first before programming the specialization. The most dominant factor is the specialization offered by the school.

\section{Bibliography}

Andi, H. N. (1985). Anak-Anak Berbakat Pembinaan dan Pendidikannya. CV Rajawali. Arikunto, S. (2006). Prosedur Peneltian Suatu Pendekatan Praktek. PT. Rineka Cipta.

Arisanty, D., \& Efendi, M. (2017). Penggunaan Model Pembelajaran Latihan Penelitian untuk Meningkatkan Hasil Belajar Geografi MA Darul Ilmi Banjarbaru, Kalimantan Selatan. Prosiding Konvensyen Kebangsaan Sekolah Kluster Kecemerlangan, 264.

Astuti, M. Y., Sari, I. P., \& Fahmi, R. A. (2020). Pemetaan Asal Sekolah, Prestasi Akademik dan Non Akademik Dalam Upaya Meningkatkan Kualitas Input Mahasiswa Fakultas Ilmu Agama Islam Universitas Islam Indonesia. at-thullab Jurnal Mahasiswa Studi Islam, 2(1), 252-263.

Dalimunthe, M. I. (2020). Pengaruh Kecerdasan Emosional Dan Minat Belajar Terhadap Pemahaman Akuntansi Pada Mahasiswa Program Studi Akuntansi Di Universitas Medan Area. Jurnal Mutiara Akuntansi, 5(2), 99-108.

Efendi, M. (2014). Pengaruh model pembelajaran latihan penelitian terhadap hasil belajar geografi siswa SMA. Universitas Negeri Malang.

Efendi, M., Masriyah, M., \& Riadi, S. (2020). Islamic Contribution In The Covid-19 Pandemic Viewed From History. Abjadia, 5(2), 157-165.

Hamalik, O. (2011). Proses Belajar Mengajar (Teaching and learning process). Bumi Aksara.

Herianto, H. (2020). Telaah Kurikulum 2013: Hasil Revisi Tahun 2018.

Krianasari, D. A., \& Salsabila, A. (2020). Pengembangan Minat Siswa Kelas III SDN Jelupang 2. ISLAMIKA, 2(1), 148-160.

Kurniati, E. (2004). Pengembangan Pengalaman Belajar dan Sumber Bagi Anak Usia Dini Melalui Metode Bermain, Bernyanyi dan Bercerita.

Miles, B. M., \& Huberman, M. A. (1992). Analisis Data Kualitatif (Alih bahasa oleh Tjetjep 
Rohendi. Jakarta: UI Press.

Moleong, L. J. (2007). Metodologi Penelitian Kualitatif, Bandung: PT Remaja Rosdakarya Offset.

Nurhasanah, A., Setiawaty, D., \& Idris, F. (2012). Pengaruh Pembelajaran Teknik Jigsaw Terhadap Pemahaman Bakat Pada Siswa Kelas X-7 di SMAN 32 Jakarta. INSIGHT: Jurnal Bimbingan Konseling, 1(2), 12-18.

Putra, S. A. (2021). Minat Siswa dalam Memilih Program Keagamaan di Madrasah Aliyah Darul Ilmi Kelas X Tahun Ajaran 2020/2021. FTK-UIN Antasari: Banjarmasin.

Rahmadani, A. T. (2016). Pengaruh Faktor Internal Dan Faktor Eksternal Terhadap Minat Siswa Memilih Jurusan IPS di Kelas XI SMA Negeri 1 Kotapinang Kabupaten Labuhanbatu Selatan. UNIMED.

Reza, A., Syukur, A., \& Soeleman, M. A. (2017). Penentuan jurusan siswa sekolah menengah atas disesuaikan dengan minat siswa menggunakan Algoritma Fuzzy C-Means. Jurnal Cyberku, 13(1).

Slameto, B. (2003). Belajar dan Faktor-Faktor yang Mempengaruhinya (Cetakan IV). Rineka Cipta.

Sudarmono, S., Apuanor, A., \& Lasenia, N. D. (2018). Analisis Faktor Minat Siswa Memilih Jurusan TKJ Pada SMK Negeri 2 Sampit. Jurnal Paedagogie Media Kependidikan, Keilmuan dan Keagamaan, 6(2), 107-115.

Sugiyono. (2008). Metode penelitian pendidikan:(pendekatan kuantitatif, kualitatif dan R $\mathcal{E} D)$. Alfabeta.

Sujianto, A. (2020). Psikologi kepribadian. Bumi Aksara.

Sukardi, D. K., \& Sumiati, D. M. (1993). Kamus istilah bimbingan dan penyuluhan. Usaha Nasional.

Syafi'i, A., Marfiyanto, T., \& Rodiyah, S. K. (2018). Studi tentang prestasi belajar siswa dalam berbagai aspek dan faktor yang mempengaruhi. Jurnal Komunikasi Pendidikan, 2(2), 115-123.

Uzer Usman, M. (2009). Menjadi guru profesional. Remaja Rosda Karya.

Zulaeha, S. (2013). Implementasi Program Kelas Peminatan di MTs Negeri Tangerang II Pamulang. FITK UIN Jakarta.

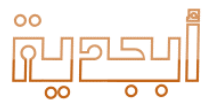

